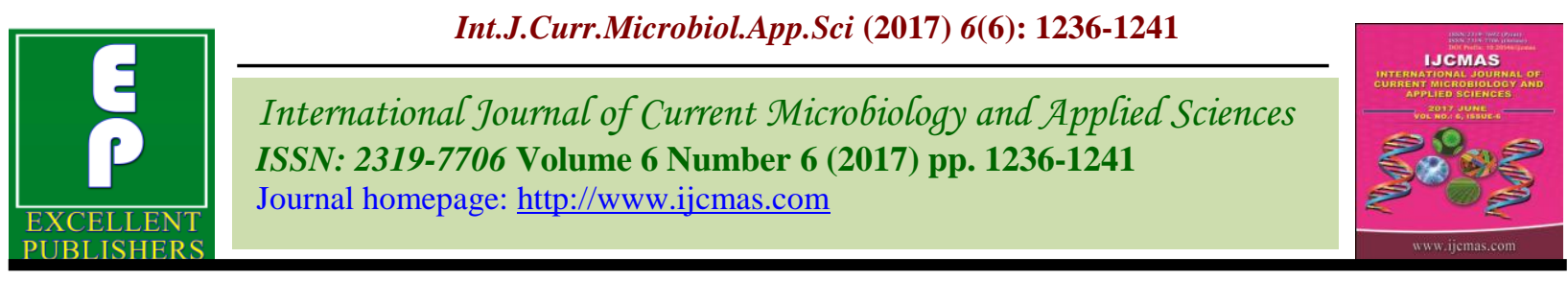

Original Research Article

https://doi.org/10.20546/ijcmas.2017.606.144

\title{
Effect of NAA, BA and Kinetin on Yield of African Marigold (Tagetes erecta Linn.)
}

\author{
S. Bairwa ${ }^{1 *}$ and J.S. Mishra ${ }^{2}$ \\ Department of Horticulture, S.K.N. College of Agriculture (S.K.R.A.U., Bikaner), Jobner, \\ Jaipur-303329 (Rajasthan), India \\ *Corresponding author
}

\section{A B S T R A C T}

\section{Keywords}

African marigold, plant growth regulators (PGRs), Naphthalene Acetic Acid (NAA), Benzyladenine (BA), Kinetin.

Article Info

Accepted: 17 May 2017 Available Online: 10 June 2017
A field experiment was conducted to study the effect of NAA, BA and Kinetin on growth of African marigold during rabi season of 2009-10. The trial was conducted in a completely randomized block design with ten treatments in three replications. The treatments comprised of three level each of NAA $(100,200,300$ $\mathrm{ppm}), \mathrm{BA}(25,50,75 \mathrm{ppm})$ and kinetin $(50,100,150 \mathrm{ppm})$ thus, making 10 treatments including absolute control. The result of the present study indicated that application of NAA, BA and Kinetin significantly increased the growth and yield at different levels and among these. Among different treatment, application of NAA had more pronounced effect on growth and yield of African marigold as compared to BA and Kinetin. NAA @ 300 ppm recorded maximum plant height $(77.26 \mathrm{~cm})$, number of branches $(14.53)$, plant spread $\left(60.80 \times 56.86 \mathrm{~cm}^{2}\right)$, number of flowers per plant (57.60), average weight of flowers $(12.93 \mathrm{~g})$, average diameter of flowers $(9.20 \mathrm{~cm})$ and yield of flowers per plant $(744.7 \mathrm{~g})$, per plot $(7.36 \mathrm{~kg})$ and per hectare $(170.37 \mathrm{q})$.

\section{Introduction}

Marigold (Tagetes erecta Linn.) is an annual flower to cultivate easily and have wide adaptability to different soil and climatic conditions. It belongs to family Compositeae and native of India. It has a great economic potential for loose flower trade. It is especially used for making garland, decoration and induced in landscape plans due to its variable height and colour. Marigolds have also great medicinal importance i.e. leaf extract is good remedy for ear-ache and flower extract is used as blood purifier and against bleeding piles. Besides, it is also found important in controlling nematodes because, it produce thiophenes, which are naturally occurring biocides. Application of NAA, BA and Kinetin showed tremendous potential in modulating growth and related processes in different crops. They are considered bio-soft wards, which elicit rapid as well as long term responses in crop plants (Yadav et al., 1994 and Malik et al., 1996). NAA is an important growth substance, which stimulates the cell division, cell enlargement and cell elongation in apical region. BA and kinetin are cytokinin which has been found essential for growth and development of plant organs, retention of 
chlorophyll, translocation of nutrient (Pandey and Sinha, 1984). Considering the importance of NAA, BA and Kinetin to find out the best growth regulators and its concentration in response of yield of African marigold.

\section{Materials and Methods}

The experiment was undertaken on African marigold (Tagetes erecta Linn.) var. Cracker Jack" at Horticultural Farm, Department of Horticulture, SKN College of Agriculture (S.K.R.A.U., Bikaner) campus-Jobner. The soil of experimental plot was loamy sand with $8.10 \mathrm{pH}$ and $1.20 \mathrm{dSm}^{-1} \mathrm{EC}$ at $25^{\circ} \mathrm{C}$. The experiment was laid out in a RBD (Randomized Block Design) with three replications. The randomization of the treatments was done with the help of random number table. Crop was raised during rabi season of 2009-10 and plot size was 2.4 x 1.8 $\mathrm{m}^{2}$ maintaining $60 \times 45 \mathrm{~cm}$ spacing, so single plot contains 16 plants. The treatments comprised of three level each of NAA (100, 200, $300 \mathrm{ppm}), \mathrm{BA}(25,50,75 \mathrm{ppm})$ and kinetin $(50,100,150 \mathrm{ppm})$ thus, making 10 treatments including absolute control. For preparation of solution, Alchohol for NAA and $1 \mathrm{~N} \mathrm{NaOH}$ for BA and Kinetin with fresh water (Chawla, 2009) was used as sticking agent. Two successive spray of these growth substances was done at 30 and 45 DAT (days after transplanting) of seedlings. Apply recommended dose of Nitrogen, Phosphorus and Potassium (200: 100: $100 \mathrm{~kg}$ per hectare) and all essential cultural practices were followed to maintain optimum plant stand.

The growth attributes i.e. plant height, number of branches and plant spread at final picking and yield attributes i.e. number of flowers, flower weight, flower diameter and yield of flowers recorded on five randomly selected plants and duration of flowering recorded on the based on plot and average were calculated. Then parameters were subjected to statistical analysis (Panse and Sukhatme, 1995).

\section{Results and Discussion}

\section{Growth attributes}

The present investigation was shown that foliar application of plant growth regulators (rest) significantly increased vegetative growth i.e. plant height $(71.51 \mathrm{~cm})$ number of branches per plant (13.02) plant spread $\left(56.11 \times 52.17 \mathrm{~cm}^{2}\right)$ over control $(64.40 \mathrm{~cm}$, 10.93 , and $48.53 \times 45.66 \mathrm{~cm}^{2}$, respectively). Application of NAA had more pronounced effect on plant growth $(73.95 \mathrm{~cm})$, number of primary branches per plant (13.93) and plant spread $\left(58.31 \times 54.62 \mathrm{~cm}^{2}\right)$ as compared to BA $\left(69.68 \mathrm{~cm}, 12.11\right.$ and $52.75 \times 49.51 \mathrm{~cm}^{2}$, respectively) and Kinetin $(70.89 \mathrm{~cm}, 13.02$, $57.26 \times 52.40 \mathrm{~cm}^{2}$, respectively) (Table 1).

Further, application of NAA @ 300 ppm recorded maximum plant height (77.26), number of branches per plant (14.53) and plant spread $\left(60.80 \times 56.86 \mathrm{~cm}^{2}\right)$ over NAA @ $100 \mathrm{ppm}\left(70.00 \mathrm{~cm}, 13.20,55.46 \times 51.86 \mathrm{~cm}^{2}\right.$, respectively). NAA @ 300 ppm was statistically identical with NAA @ 200 ppm. This increased in plant height, number of branches per plant and plant spread with increasing levels of NAA, might be due to the fact of NAA, being a member of auxin group, promotes vegetate growth by active cell division, cell enlargement and cell elongation. Another probable reason to increased plant growth may be the osmotic uptake of water and nutrient under the influence of NAA. Primary physiological effect of auxin is to stimulate the elongation of cells due to increase amylase activity, permeability of cell wall and formation of energy rich phosphate (ATP) which would have been utilized by plants for cellular expansion and tissue growth resulting in more vegetative growth of the plant (Pandey and Sinha, 1984). These 
results are in close conformity with those of Kumar et al., (2008) in gladiolus, Mukhopadhayay and Mukhopadhayay (1990) in Carnation. Therefore, application of BA and Kinetin increased the vegetative growth i.e. plant height, number of branches per plant and plant spread with increasing levels. Application of BA was found significantly variation in plant height, number of branches per plant and plant spread at but application of Kinetin was found non-significant in respect of vegetative growth of plant. This increased in vegetative growth might be due to the fact that BA and Kinetin are the member of cytokinin. Cytokinin enhanced the cell division as well as cell elongation. These results have also been inconsonance with Sonvir et al., (2002), Kim et al., (2003), Barman and Rajani (2004) and Kumar et al., (2006) (Table 2).

Table.1 Effect of NAA, BA and Kinetin on growth of African marigold

\begin{tabular}{|l|c|c|c|c|}
\hline Treatments & Plant height & Number of branches & \multicolumn{2}{|c|}{ Plant spread $\left(\mathrm{cm}^{2}\right)$} \\
\cline { 3 - 5 } & $(\mathrm{cm})$ & per plant & North-South & East-West \\
\hline Control & 64.40 & 10.93 & 48.53 & 45.66 \\
\hline Rest & 71.51 & 13.02 & 56.11 & 52.17 \\
\hline SEm \pm & 3.02 & 0.55 & 2.27 & 2.11 \\
\hline $\mathrm{CD}(\mathrm{p}=0.05)$ & 8.56 & 1.56 & 6.43 & 5.99 \\
\hline & & & & 54.62 \\
\hline NAA & 73.95 & 13.93 & 58.31 & 49.51 \\
\hline BA & 69.68 & 12.11 & 52.75 & 52.40 \\
\hline Kinetin & 70.89 & 13.02 & 57.26 & 1.00 \\
\hline SEm \pm & 1.42 & 0.26 & 1.07 & 2.82 \\
\hline CD $(\mathrm{p}=0.05)$ & 4.04 & 0.74 & 3.03 & \\
\hline
\end{tabular}

Table.2 Effect of different levels of NAA, BA and Kinetin on growth of African marigold

\begin{tabular}{|l|c|c|c|c|}
\hline Treatments & \multirow{2}{*}{ Plant height $(\mathrm{cm})$} & $\begin{array}{c}\text { Number of branches } \\
\text { per plant }\end{array}$ & \multicolumn{2}{|c|}{ Plant spread $\left(\mathrm{cm}^{2}\right)$} \\
\cline { 3 - 5 } & 70.00 & 13.20 & North-South & East-West \\
\hline NAA 100 ppm & 74.60 & 14.06 & 55.46 & 51.86 \\
\hline NAA 200 ppm & 77.26 & 14.53 & 60.86 & 55.13 \\
\hline NAA 300 ppm & 2.47 & 0.45 & 1.85 & 56.86 \\
\hline SEm \pm & 6.99 & 1.28 & 5.25 & 1.73 \\
\hline CD $(\mathrm{p}=0.05)$ & 65.06 & 10.66 & 50.00 & 4.89 \\
\hline BA 25 ppm & 69.66 & 12.60 & 52.93 & 49.80 \\
\hline BA 50 ppm & 74.33 & 13.06 & 55.33 & 52.00 \\
\hline BA 75 ppm & 2.47 & 0.45 & 1.85 & 1.73 \\
\hline SEm \pm & 6.99 & 1.28 & 5.25 & 4.89 \\
\hline CD $(p=0.05)$ & & & & 49.80 \\
\hline & 67.73 & 12.60 & 54.73 & 52.73 \\
\hline Kinetin 50 ppm & 71.00 & 13.00 & 57.66 & 54.66 \\
\hline Kinetin 100 ppm & 73.93 & 13.46 & 59.40 & 1.73 \\
\hline Kinetin $150 \mathrm{ppm}$ & 2.47 & 0.45 & 1.85 & $\mathrm{NS}$ \\
\hline SEm \pm & $\mathrm{NS}$ & $\mathrm{NS}$ & $\mathrm{NS}$ & \\
\hline CD $(\mathrm{p}=0.05)$ & & & & \\
\hline
\end{tabular}

$\mathrm{NS}=$ non-significant 
Table.3 Effect of NAA, BA and Kinetin on yield of African marigold

\begin{tabular}{|l|c|c|c|c|c|c|}
\hline Treatments & $\begin{array}{c}\text { Number } \\
\text { of flowers } \\
\text { per plant }\end{array}$ & $\begin{array}{c}\text { Average } \\
\text { weight of } \\
\text { flowers(g) }\end{array}$ & $\begin{array}{c}\text { Average } \\
\text { diameter of } \\
\text { flowers(cm) }\end{array}$ & $\begin{array}{c}\text { Yield of } \\
\text { flowers per } \\
\text { plant }(\mathrm{g})\end{array}$ & $\begin{array}{c}\text { Yield of } \\
\text { flowers per } \\
\text { plot(kg) }\end{array}$ & $\begin{array}{c}\text { Yield of } \\
\text { flowers per } \\
\text { hectare(q) }\end{array}$ \\
\hline Control & 41.93 & 10.60 & 6.20 & 444.45 & 4.42 & 102.31 \\
\hline Rest & 51.81 & 12.20 & 7.78 & 633.97 & 6.31 & 146.03 \\
\hline SEm \pm & 2.10 & 0.49 & 0.31 & 25.51 & 0.25 & 5.88 \\
\hline CD $(\mathrm{p}=0.05)$ & 5.94 & 1.40 & 0.88 & 72.31 & 0.72 & 16.67 \\
\hline NAA & 55.04 & 12.37 & 8.44 & 682.11 & 6.78 & 156.94 \\
\hline BA & 45.37 & 12.01 & 7.15 & 545.92 & 5.44 & 125.85 \\
\hline Kinetin & 55.02 & 12.23 & 7.75 & 673.89 & 6.71 & 155.32 \\
\hline SEm \pm & 0.99 & 0.23 & 0.15 & 12.03 & 0.12 & 2.77 \\
\hline CD $(\mathrm{p}=0.05)$ & 2.80 & NS & 0.42 & 34.09 & 0.34 & 7.86 \\
\hline
\end{tabular}

$\mathrm{NS}=$ non-significant

Table.4 Effect of different levels of NAA, BA and Kinetin on yield of African marigold

\begin{tabular}{|l|c|c|c|c|c|c|}
\hline Treatments & $\begin{array}{c}\text { Number } \\
\text { of flowers } \\
\text { per plant }\end{array}$ & $\begin{array}{c}\text { Average } \\
\text { weight of } \\
\text { flowers(g) }\end{array}$ & $\begin{array}{c}\text { Average } \\
\text { diameter of } \\
\text { flowers(cm) }\end{array}$ & $\begin{array}{c}\text { Yield of } \\
\text { flowers per } \\
\text { plant(g) }\end{array}$ & $\begin{array}{c}\text { Yield of } \\
\text { flowers per } \\
\text { plot(kg) }\end{array}$ & $\begin{array}{c}\text { Yield of } \\
\text { flowers per } \\
\text { hectare(q) }\end{array}$ \\
\hline NAA 100 ppm & 52.40 & 11.73 & 7.53 & 614.65 & 6.13 & 141.89 \\
\hline NAA 200 ppm & 55.13 & 12.46 & 8.60 & 686.91 & 6.85 & 158.56 \\
\hline NAA 300 ppm & 57.60 & 12.93 & 9.20 & 744.76 & 7.36 & 170.37 \\
\hline SEm \pm & 1.71 & 0.40 & 0.25 & 20.83 & 0.21 & 4.80 \\
\hline CD $(\mathrm{p}=0.05)$ & 4.85 & 1.14 & 0.72 & 59.04 & 0.59 & 13.61 \\
\hline & & & & & & \\
\hline BA 25 ppm & 42.18 & 11.33 & 6.60 & 477.89 & 4.74 & 109.72 \\
\hline BA 50 ppm & 45.76 & 12.16 & 7.26 & 556.44 & 5.55 & 128.47 \\
\hline BA 75 ppm & 48.16 & 12.53 & 7.60 & 603.44 & 6.02 & 139.35 \\
\hline SEm \pm & 1.71 & 0.40 & 0.25 & 20.83 & 0.21 & 4.80 \\
\hline CD $(\mathrm{p}=0.05)$ & 4.85 & 1.14 & 0.72 & 59.04 & 0.59 & 13.61 \\
\hline & & & & & & \\
\hline Kinetin 50 ppm & 51.97 & 11.52 & 6.86 & 598.69 & 5.98 & 138.42 \\
\hline Kinetin 100 ppm & 55.86 & 12.26 & 7.93 & 684.84 & 6.80 & 157.40 \\
\hline Kinetin 150 ppm & 57.22 & 12.90 & 8.46 & 738.13 & 7.35 & 170.13 \\
\hline SEm \pm & 1.71 & 0.40 & 0.25 & 20.83 & 0.21 & 4.80 \\
\hline CD $(\mathrm{p}=0.05)$ & 4.85 & 1.14 & 0.72 & 59.04 & 0.59 & 13.61 \\
\hline
\end{tabular}

\section{Yield attributes}

The application of plant growth regulators (rest) brought perceptible variation in number of flowers (51.81), flower weight (12.20 g), flower diameter $(7.78 \mathrm{~cm})$ and yield of flowers per plant $(633.97 \mathrm{~g})$, per plot (6.31 $\mathrm{kg}$ ) and per hectare (146.03 q) as compared to control $(41.93,10.60 \mathrm{~g}, 6.20 \mathrm{~cm}, 444.45 \mathrm{~g}$ $4.42 \mathrm{~kg}$ and $102.31 \mathrm{q}$, respectively). Among different PGRs, application NAA recorded maximum number of flower per plant (55.04), average flower weight $(12.37 \mathrm{~g})$ and diameter $(8.44 \mathrm{~cm})$, yield of flowers per plant $(682.11$ 
g), per plot $(6.78 \mathrm{~kg})$ and per hectare $(156.94$ q) (Table 3).

Application of NAA @ 300 ppm recorded significantly higher number of flower per plant (57.60), average flower weight (12.93 g) and diameter $(9.20 \mathrm{~cm})$, yield of flowers per plant $(744.76 \mathrm{~g})$, per plot $(7.36 \mathrm{~kg})$ and per hectare $(170.37$ q) over $100 \mathrm{ppm}$ (52.40, $11.73 \mathrm{~g} 7.53 \mathrm{~cm}, 614.65 \mathrm{~g}, 6.13 \mathrm{~kg}$ and 141.89 q, respectively) and it was found statistically identical with $200 \mathrm{ppm}$. This increase in yield characters might be due to fact that NAA enhance cell division and rate of the plants for cellular expansion and tissue growth. NAA, being an auxin it stimulate vegetative growth, regulate flowering and also prevent abscission of leaves and pre mature flower buds. Similar results have also been obtained by Chodhaury and Khandelwal (2008) in gladiolus, Singh (2003) in French marigold. Sharma et al., (1995) found increase in plant height of chrysanthemum with increasing levels of NAA from 25 to 100 ppm spray. Thus, application of BA @75 ppm and Kinetin@150 ppm significantly increased yield characters over their lower concentrations. BA and Kinetin being cytokinin, these induce the flowering might be due to ability to alter the osmotic distributions i.e. the theory of nutrient diversion (Sachs et al., 1979). The above findings are in close agreement with finding of Sonvir et al., (2002), Kim et al., (2003), Barman and Rajni (2004) and Choudhary (2008) in gladiolus (Table 4).

The application of NAA, BA and Kinetin significantly increased growth and yield characters. Among these, application of NAA had more pronounced effect on growth and yield characters as compared to BA and Kinetin. Different concentration of NAA, BA and Kinetin was found significant difference on growth and yield. Among different concentrations of NAA, NAA @ 300 ppm recorded significantly higher plant height $(77.26 \mathrm{~cm})$, number of branches per plant (14.53), plant spread $\left(60.80 \times 56.86 \mathrm{~cm}^{2}\right)$ number of flower per plant (57.60), average flower diameter $(9.20 \mathrm{~cm})$ and weight $(12.93$ g) and yield of flowers per plant (744.76 g), per plot $(7.36 \mathrm{~kg})$ and per hectare $(170.37 \mathrm{q})$.

\section{References}

Barman, D. and Rajni, K., 2004. Effect of chemicals on dormancy breaking, growth, flowering and multiplication in gladiolus. J. Ornamental Horticul., 7(1): 38-44.

Chawla, H.S. 2009. Introduction to plant biotechnology. Published by oxford and IBH Publication Pvt. Ltd. New Delhi. pp. 18-27.

Choudhary, D.K. 2008. Effect of plant growth regulators on growth, floral characters, vase life and corm production of gladiolus (Gladiolus grandiflorum L.). M.Sc. Thesis (Horticulture), submitted to Rajasthan Agricultural University, Bikaner Campus- Jobner.

Kim, S.D., Kim, H.H., Lee, H.D., J.W. and Yun, T. 2003. Effect of growth regulators on occurrence of suckers, lateral shoot elongation and cut flower quality in secondary flowering of Dendranthema grandiflorum 'Beagkwang'. J. Korean Soc. Horticult. Sci., 44(4): 335-538.

Kumar, N.P., Reddy, Y.N. and Chandrashekar, R. 2006. Flower induction in Gladiolus cormels by application of chemicals. J. Ornamental Horticulturae, 9(30): 174-178.

Kumar, P.S., Bhagawati, R., Kumar, R., and Ronya, T. 2008. Effect of plant growth regulators on vegetative growth, flowering and corm production of gladiolus in Arunachal Pradesh. $J$. Ornamental Horticulture, 11(4): 265270. 
Malik, C.P., Sanjeev, K. and Bhatia, D.S. 1996. Alternating plant archetypes with PGRs and genetic transformation biological soft wards in agro biotechnology. Agro Annual Rev. Plant Physiol., 2: 13-64.

Mukhopadhyay, A. and Mukhopadhyay, A. 1990. Response of carnation to foliar application of NAA and gibberellic acid. Haryana J. Horticult. Sci., 19(34): 280-283.

Pandey, S.N. and Sinha, B.K. 1984. Role of Auxin. Plant Physiol., Vikash Publishing House, New Delhi. pp. 432436.

Panse, V.G. and Sukhatme, P.V. 1995. Statistical Methods for Agricultural Workers. ICAR, New Delhi.

Sachs, R.M., Hacket, W.P., Ramina, A. and Maloof, C. 1979. Photosynthetic assimilation and nutrient diversion as controlling factors in flower initiation in Bougainvillea and Nicotiana tobacum cv. Wis 38. In: Marcelle R, Clystors H and Van Poucke M (Eds.). Photosynthesis and Plant Development, Dr. W. Junk, The Hague, pp. 95-102.
Sharma, H.G., Verma, L.S., Jain, V. And Tiwari, B.L. 1995. Effect of foliar application of some plant growth regulators on growth and flowering of chrysanthemum var. Move in Carvin. Orissa J. Horticult., 23(1-2): 61-64.

Singh, A.K. 2003. Effect of plant bioregulators on growth, biomass and flowering in French marigold (Tagetes petula). Indian Perfumer, 47(3): 279284.

Sonvir, S., Ramesh, K., Manreet, S., Sooch, S., Kumar, R., Sooch, M., Misra, R.L. and Sanyat, M. 2002. Effect of NAA and kinetin on plant growth and flower production in carnation. Floriculture Research Tend in India. In: Proceedings of the National Symposium on Indian Floriculture in New Millennium held at Bangalore from 25-27 February, 295297.

Yadav, N., Yadav, N.K. and Kumar, A., 1994. Effect of BA on transpiration, water potential and its components in genotypes of wheat contrasting in drought tolerance. J. Agron. Crop Sci., 173: 61-68.

\section{How to cite this article:}

Bairwa, S. and Mishra, J.S. 2017. Effect of NAA, BA and Kinetin on Yield of African Marigold (Tagetes erecta Linn.). Int.J.Curr.Microbiol.App.Sci. 6(6): 1236-1241.

doi: https://doi.org/10.20546/ijcmas.2017.606.144 